\title{
Training nurses to save lives of malnourished children
}

\section{T Puoane, Dr PH}

School of Public Health, University of the Western Cape

\author{
D Sanders, M.B. Ch B
}

School of Public Health, University of the Western Cape

\author{
A Ashworth, PhD \\ Nutrition and Public Health Intervention Research Unit, London School of Hygiene \& Tropical Medicine, UK
}

\author{
M Ngumbela, B (Cur) \\ Eastern Cape Department of Health
}

\section{Keywords:}

Malnourishment, attitudes, WHO treatment guidelines

\section{Correspondence address:}

Dr Thandi Puoane

School of Public Health.

University of the Western Cape,

Private Bag X17,

Bellville 7535,

South Africa.

Tel : (021) 959-2809

Fax: (021) 959-2872

E-mail : tpuoane@uwc.ac.za

\section{Abstract: Curationis 29(1): 73-78}

A qualitative study with a pre- and post-intervention component was undertaken among 66 professional nurses at 11 hospitals in the Eastern Cape to assess their perceptions and attitudes towards severely malnourished children and their mothers/ caregivers. Nurses' attitudes were compared before and after attending a 5-day training course to improve the management of malnutrition along with implementing World Health Organization (WHO) guidelines.

Severe malnutrition is a major cause of death among paediatric patients in many hospitals in South Africa. A qualitative study with a pre- and post-intervention component was undertaken among 66 professional nurses at 11 hospitals in the Eastern Cape to assess their perceptions and attitudes towards severely malnourished children and their mothers/caregivers. Nurses' attitudes were compared before and after attending a 5-day training course to improve the management of severe malnutrition through implementing the World Health Organisation (WHO) guidelines.

Foc us group discussions were conducted in isiXhosa following a semi-structured discussion guide. Three themes emerged from these discussions, i.e. nurses placed blarne on the mothers for not giving adequate care at home; nurses valued malnourished children less than those with other conditions; and nurses felt resentment towards caregivers. Underlying reasons for the negative attitudes towards severely mal nourished children and their caregivers were misunderstandings of the causes of mal nutrition, misinterpretation of clinical signs, especially poor appetite, and high mortality during treatment.

However, the training course and successful application of the treatment guidelines altered these perceptions and helped nurses to have a better understanding of the causes of the presenting clinical signs. These nurses have begun advocating for raised awareness of the physiological differences that occur in malnutrition and the need to include the WHO Ten Steps of treatment in the nursing curricula and inservice training. A cadre of volunteer nurse-trainers has been formed in Eastern Cape. Experience in this province has shown that in-service training changes attitudes to mal nutrition and treatment practices, as well as saving lives.

\section{Opsomming}

Erge wanvoeding is 'n hoofoorsaak van sterfte onder pediatriese pasiënte in verskeie hospitale. 'n Kwalitatiewe studie met 'n voorafgaande en agtereenvolgende intervensiekomponent is onder 66 professionele verpleegkundiges by 11 hospitale in 
die Oos-Kaap onderneem om hulle persepsies en houdings jeens erge ondervoede kinders asook teenoor hulle moeders/versorgers vas te stel. Verpleegkundiges se houdings is vergelyk voor en na 'n 5-dag opleidingskursus om die beheer van wanvoeding te verbeter deur middel van die implementering van die Wêreldgesondheidsorganisasie (WGO) se riglyne.

Ingestelde groepbesprekings is in isiXhosa gevoer met behulp van 'n semigestruktureerde besprekingsgids. Drie temas het uit hierdie besbrekings na vore gekom, i.e. verpleegkundiges het skuld op moeders geplaas weens nalatige versorging, verpleegkundiges het minder waarde aan ondervoede kinders geheg as aan diegene met ander toestande, en verpleegkundiges het gegriefd teenoor versorgers gevoel. Onderliggende redes vir die negatiewe houdings teenoor erge wangevoede kinders en hulle versorgers was wanopvattings ten opsigte van die oorsake van wanvoeding, misinterpretasie van die kliniese tekens, veral 'n swak aptyt en die hoë mortaliteit gedurende behandeling.

Nogtans het die opleidingskursus en suksesvolle toepassing van die behandelingsriglyne hierdie persepsies gewysig en verpleegkundiges gehelp om 'n beter begrip te hê van die oorsake van die kliniese tekens wat teenwoordig is. Hierdie verpleegkundiges het begin bepleit vir 'n groter bewustheid, van die fisiologiese verskille wat gepaardgaan met wanvoeding en die behoefte aan die insluiting van die WGO se Tien Stappe van behandeling by die verplegingskurrikula en indiensopleiding. 'n Kader vrywilliger verpleeginstrukteurs is in die Oos-Kaap gevorm. Ondervinding in hierdie provinsie het getoon dat indiensopleiding houdings jeens wanvoeding en behandelingspraktyke verander, asook lewens red.

Oh no! It's a Kwashy again. Look at you (the mother); you are well-dressed while the child is malnourished. What is wrong with these mothers?

They (the children) are supposed to die anyway. They are not important.

Listening to these comments by two senior nurses makes one wonder why attitudes towards malnourished children and their mothers differ from those towards other sick children. What is the reason for perceiving their admission to the ward as a burden?

\section{Introduction}

Malnutrition in children remains a leading cause of morbidity and mortality in South Africa, and severe malnutrition is a major cause of death among paediatric patients in many hospitals. The reason for the latter is not that there are more admissions for severe malnutrition than for other conditions but rather because a greater proportion of them die during treatment. For example, in 11 rural hospitals in the Eastern Cape Province, on average 22\% of paediatric admissions with severe malnutrition died during the first half of 2004 compared to $9 \%$ of children with other conditions. Many malnourished children die unnecessarily because of outdated practices and staff members who are unaware of their special needs (Ashworth, Chopra, McCoy, Sanders, Jackson, Karaolis, Sogaula \& Schofield, 2004:1110).

Severely malnourished children are often known to be miserable, irritable, and anorexic. If basic principles of treatment are not followed, recovery is slow and typically, 20-30\% of these children die (Schofield \& Ashworth, 1996:223). In some South African hospitals, mortality among severely malnourished children approaches $50 \%$ (Puoane, Sanders, Chopra, Ashworth, Strasser, McCoy, Zulu, Matinise \& Mdingazwe, 2001:138). In such circumstances, it is perhaps not surprising that their arrival at the ward often leads to frustration and irritation among nurses.

In an effort to reduce deaths from malnutrition and improve recovery, the World Health Organization (WHO, 2000: 80-91) guidelines for managing severe malnutrition (WHO, 2000:1-162) were piloted in two rural hospitals of the Eastern Cape, in 1998. Key messages based on the WHO's Ten Steps were formulated, and a training course and guide (Ashworth, Puoane, Sanders \& Schofield, 2003:1-206) were developed to facilitate implementation in other hospitals in southern Africa. Until now, health professionals from 27 South African hospitals have been trained.

This article reports on the attitudes of nurses towards severely malnourished children and their mothers/caregivers, and how these attitudes changed after having attended a training course along with implementing the WHO guidelines. The authors also report on how attitudes influence the quality of care.

Severe malnutrition is defined as severe wasting and/or oedema (WHO, 2000:80) and includes the syndromes of kwashiorkor (oedematous malnutrition), marasmus (severe wasting), and marasmic kwashiorkor (severe wasting with oedema).

\section{Setting}

The project is based in the former Transkei, an apartheid-era homeland, situated in one of the most underresourced regions in South Africa. This area includes three districts and 11 hospitals, i.e. Alfred Ndzo district (Mary Theresa, Mt Ayliff, Sipetu, Rietvlei, and St Margaret's Hospitals), O.R. Tambo district (St Patrick's, Greenville, Holy Cross, St Elizabeth and Bambisana Hospitals), and part of Ukahlamba district (Taylor Bequest Hospital).

\section{Training course and materials}

The Eastern Cape Department of Health has supported the training of hospital staff since 1999 to improve the management of severe malnutrition with a 5-day course developed by the University of the Western Cape and the London School of Hygiene and Tropical Medicine. The course is interactive and participatory, and involves:

- $\quad$ group work, to provide an opportunity for self-learning through logical reasoning and resolving problems, and promote deep learning that will not be forgotten;

- $\quad$ role-plays, to facilitate discussions and raise sensitive issues, and to illustrate physiological mechanisms and difficult concepts in a memorable and light-hearted way;

- $\quad$ practical exercises to test knowledge and practise new skills;

- questions and answers, to draw forth knowledge and apply this to managing malnourished children;

- $\quad$ key messages, as a summary of the principles for managing severely malnourished children (see Box 1);

- $\quad$ action plans, to help participants plan how they will improve their practices on returning to their hospitals. 
The course and materials follow the principles of care set out by the WHO for managing severe malnutrition (WHO, 2000:80-91). In 2000, the development of a Training Guide was undertaken to help others organise and teach this course, and thus accelerate replication and implementation (Ashworth, et al., 2003:1206). The Guide contains all the course materials that trainers and the training Director will require. Handouts and transparencies used during the course could be used by participants to train their own staff when they return to their respective hospitals. The course content has also been summarised in a book, 'Caring for severely malnourished children' (Ashworth \& Burgess, 2003:179).

\section{Methods}

This qualitative study assessed the perceptions and attitudes of nurses towards severely malnourished children and their mothers/caregivers, with a preand post-intervention component in which attitudes were compared before and after attending a training course and implementing the WHO guidelines.

\section{Target population}

Participants included 66 professional nurses who were directly involved in the care of malnourished children in 11 firstreferral level hospitals in the Eastern Cape and who participated in the training programme described above. Participants from each hospital included the sisterin-charge of the paediatric ward, her deputy-in-charge, and the paediatric zonal matron.

\section{Data collection}

Data were collected by two of the authors (TP and MN) in three phases: i) before the training workshops, ii) during training workshops, and iii) 6-12 months after the training workshops.

Phase (i). Before each of the six training workshops during 2000/01, focus group discussions were conducted in isiXhosa with 8-10 senior nursing staff to assess their perceptions of and attitudes towards malnourished children and their caregivers. A semi-structured discussion guide was followed. Causes of malnutrition and prognosis were also addressed. In-patient case-management practices were ascertained at baseline by comparing these to the WHO guidelines (WHO, 2000:80-91), and the adequacy of resources for the care of malnourished children was assessed (Puoane, Sanders, Ashworth, Chopra, Strasser \& McCoy 2004:35-39). Case-fatality rates were calculated by dividing the number of deaths of severely malnourished children by the number of severely malnourished admissions times 100 .

Phase ii). During the six training workshops, nurses were given a scenario and requested to display attitudes towards malnourished children through role-play:

"You are a nurse working in a paediatric ward. During the past two weeks, there have been admissions of malnourished children on a daily basis. You have been busy giving out medicines when you suddenly see a mother sitting in a chair with a malnourished child. Please display your attitude towards this mother".

Phase (iii). After 6-12 months, evaluation visits to the 11 hospitals were made to gather data about case-fatality rates and the extent to which the guidelines were being followed with the use of a checklist. Previously trained nurses who had been implementing the guidelines for about 612 months were also invited to the workshops to share their pre- and posttraining experiences of casemanagement. Two nurses were invited to each training workshop with 12 nurses sharing their experiences.

\section{Data quality}

Triangulation (i.e. comparing data obtained by one method with similar data obtained by another method) was used to demonstrate validity of the qualitative findings. For example, attitudes towards the arrival of a malnourished child on the ward obtained through focus-group discussions were compared with those displayed in role-plays. Information was also referred back to participants to ensure trustworthiness of data.

\section{Data analysis}

Discussions were transcribed, translated into English, and analysed for content to identify the main themes. Direct quotes from the focus groups, role-plays, and testimonies were used to illustrate perceptions and attitudes.

\section{Ethics}

Ethical approval was obtained from the Ethics Committee of the University of the
Western Cape. All participants who consented to the study were informed of their right to refuse participation or withdraw from the study without having to give reasons. Participants were guaranteed confidentiality.

\section{Findings}

\section{In-patient care practices}

The findings on the "In-patients care practices" and "Attitudes towards the children and carers" are findings at baseline (i.e. before the intervention). The "Testimonies of nurses who had been trained previously" is after the intervention. At baseline, quality of care was reasonably satisfactory at Rietvlei Hospital, with a case-fatality rate of $10 \%$, but elsewhere treatment of severe malnutrition was inappropriate and none of the Ten Steps was adequately practised. Triage was absent and there were long delays in admitting children to the ward. Diuretics were incorrectly prescribed to treat oedema thereby greatly increasing their risk of heart failure. Children with diarrhoea often received intravenous (IV) fluids indiscriminately, thereby greatly increasing their risk for heart failure, antibiotics were not routinely prescribed, and electrolyte and micronutrient deficiencies were not corrected. Special feeds were not prepared and malnourished children simply received smaller portions of the general adult ward diet. They went without food for up to 11 hours at night, thus risking death from hypoglycaemia. Play and stimulation were not provided and there was no continuity of care after discharge. The hospitals lacked many basic resources including naso-gastric tubes, vitamin A capsules, multivitamins, and both paediatric and dietary scales. Wards were often cold and overcrowded. Some malnourished children were nursed in the same bed as children with other infectious conditions, including meningitis and gastroenteritis. There was no provision for mothers or carers to stay over at night, children were weighed infrequently, and hygiene was generally poor. Staff considered caring for the severely malnourished children to be unrewarding. Case-fatality rates in 1999 ranged from $10 \%$ (Rietvlei) to $45 \%$ (Holy Cross) with a median of $28 \%$.

\section{Attitudes towards the children and carers}

The three themes that emerged were that 


\begin{tabular}{|c|c|}
\hline 1. & $\begin{array}{l}\text { Prevent hypoglycaemia by feeding every } 3 \text { hours day and night. Start } \\
\text { straightaway. }\end{array}$ \\
\hline 2. & Prevent hypothermia by keeping children warm and dry day and night. \\
\hline 3. & $\begin{array}{l}\text { Too much fluid can kill. Rehydrate more slowly than usual. Do not give } \\
\text { IV fluids except in shock. }\end{array}$ \\
\hline 4. & $\begin{array}{l}\text { Electrolyte imbalance can cause heart failure. Give extra potassium and } \\
\text { magnesium. Limit sodium (salt). }\end{array}$ \\
\hline 5. & $\begin{array}{l}\text { Give broad-spectrum antibiotics even if there are no signs of infection. } \\
\text { Infections are often hidden in severe malnutrition. }\end{array}$ \\
\hline 6. & Give extra vitamin A, zinc, copper, folic acid, and multivitamins. \\
\hline 7. & $\begin{array}{l}\text { Initially, give small amounts of starter formula every } 3 \text { hours. This formula } \\
\text { is specially designed to meet energy and protein needs. }\end{array}$ \\
\hline 8. & $\begin{array}{l}\text { After loss of oedema and return of appetite, give as much catch-up } \\
\text { formula as the child can eat, at least } 7 \text { times a day. Catch-up formula } \\
\text { together with a nutrient dense diet promotes rapid weight gain. }\end{array}$ \\
\hline 9. & Provide loving care and stimulation to improve mental development. \\
\hline 10. & $\begin{array}{l}\text { Teach mothers what to feed at home. Organize regular follow-up to prevent } \\
\text { relapse and death }\end{array}$ \\
\hline & . \\
\hline
\end{tabular}

nurses blamed the mothers for not giving adequate care at home, nurses placed less value on malnourished children than on those with other conditions, and that nurses felt resentment towards caregivers.

\section{a) Blaming the victim}

Although poverty, poor living conditions, and social disadvantage are underlying causes of malnutrition, nurses tended to assume that caregivers had been negligent and that malnutrition was a direct consequence of this neglect. They tended to show little empathy to the caregivers, and barely showed awareness of the important aetiological role of infection in relation to malnutrition. Inadequate feeding was considered the sole cause of malnutrition.

They were not fed by their mothers. Why are you crying? You are responsible because you did not feed the child.

Ignorance about poor appetite being a sign of infection, micronutrient deficiency, and electrolyte imbalance particularly existed. Consequently, attitudes to poor appetite tended to be dismissive, and no action was taken.

If they do not eat, we just say you are not hungry: you will eat when you are hungry - we just pass by with food.

Nurses were quick to criticise mothers of malnourished children if they were welldressed. This was not the case with mothers of children with other conditions, and it appeared to be a stigma to have a malnourished child.

Mothers are responsible for not feeding the children: you find that a mother has a cell phone, is well-dressed, yet the child is malnourished.

\section{b) Malnourished children are less valued}

Most nurses felt that malnourished children are not ill like other patients, but are in hospital because no one at home cares about them. They reasoned that this lessened their responsibility to provide nursing care. Responses indicated that when caregivers are perceived as negligent, nurses lowered their standards of care.

Why should we take care of them if their parents left them to be sick? They are in hospital because their mothers do not care about them.

They do not eat properly; they need to be pleaded to eat; yet they are hungry. We do not have time for such children.

I (ward sister) usually tell the nurses that if the child does not want to eat then leave her, she is slowing down the ward routine.

The lives of the children were not always valued and death was often viewed as inevitable.

They are just hungry; they do not need to be admitted in hospital. They need to die anyway.

They are supposed to die anyway. They are not important.

Once w'e hear that the mother is dead, we think of HIVIAIDS; w'e know that the child will also die soon. What's the use of feeding the child anyway?

Not understanding the reasons why malnourished children need special care exacerbated the problem of poor practices:

Just put in lots of IV fluid instead of feeding them orally.

There was a profound lack of knowledge about the essentiality of giving broadspectrum antibiotics to all severely malnourished children.

\section{c) Resentment}

Trainees were given the scenario shown under Phase (ii) of the Methods, and asked to perform a role-play: typical responses are shown below. The roleplay revealed resentment and anger towards mothers of malnourished children.

Oh no! It's a Kwashy again. Look at you: you are nicely dressed while the child is malnourished. What is wrong with these mothers?

Oh! We are tired of Kwashy patients. Why don't you buy food for your children?

You are busy applying for the children's grant, but you do not use the money to feed children, then you dump them to us so that we can feed them for you.

You look nice, you even have a cell phone, but your child is like this.

\section{Testimonies of nurses who had been trained previously}

Changed attitudes were revealed when nurses who had been implementing the WHO guidelines at their own hospitals were invited to give their testimonies to current trainees. One aspect that was highlighted by the nurses was that the training had given them an understanding of the physiological changes that occur in severe 
malnutrition, which created awareness of the need to treat the children differently, including feeding, rehydration, use of antibiotics, and the importance of play. Included were the following quotes:

We thought these children have been neglected by mothers. We did not know what was going on physiologically. When I was sitting in the lecture room, I was thinking of the child that was admitted just before I left for the training (and put on a drip) and praying very hard that I must find him alive. But on arrival back to the hospital at the end of the training I found that he had died 12 hours before my arrival. I could not forgive myself.

When I was told that I was going to attend a training workshop about the management of malnourished children I asked my matron "what is new' about this Kwashy"? We have been managing these children for years! But at the end of the session on physiological changes that occur in malnourished children, I actually told the facilitators that we have killed many children thinking we were doing the correct thing by giving high protein diets and putting up intravenous fluids.

Understanding the physiological changes that occur in malnourished children and understanding they need to be treated differently from other children changed our attitudes towards them. We thought that these children lacked proteins and we therefore gave them a high protein diet.

Knowing why things should be done, such as feeding 3-hourly to prevent hypoglycaemia changed our attitude. We thought sister-in-charge was just increasing our workload unnecessarily, so we sometimes recorded the feeds without giving them to the child. After implementing the programme and limiting intravenous fluids and giving proper feeds (starter formula), we saw a difference in statistics (fewer deaths) and felt good about it.

We never used to give antibiotics even if prescribed; we thought that these children only needed to be fed.

We did not know that play and stimulation forms part of the management, so we just left these children to lie dow'n in the cot-beds without playing with them. Instead, we give them names to suit their appearance or just call them KwashyKuashy.

When we touch them, they start crying, we therefore prefer to leave them alone. Smiling is a sign of recovery. Evervone should be trained about the management of severe malnutrition. It should be included in the basic nursing curriculum.

The training also changed their attitude towards caregivers and they spoke about, needing to be sympathetic to mothers. When the mother arrives with a malnourished child, w'e now explain why the child is sick. We also explain the type of feeds that will be given.

\section{Case-fatality rates}

Overall, median case-fatality rates fell from $28 \%$ to $22 \%$ after training. A striking example was Holy Cross Hospital where the mortality among severely malnourished patients was $45 \%$ in 1999 , and fell to $8 \%$ within twelve months of the staff being trained. Not all hospitals have experienced such dramatic changes: the reasons are varied but include frequent staff turnover, emigration, staff illness, poor leadership, and lack of supervision and accountability (Ashworth, et al., 2004:1110-1115).

\section{Discussion}

Severely malnourished children are commonplace in rural hospitals in South Africa. The care of severely malnourished children is primarily nurseled. Nurses are their lifeline; therefore, it is essential that they have the knowledge and skills to make the correct decisions on the management of these children. However, this is not happening. Their knowledge is inadequate, and treatment practices are poor and do not follow international guidelines. In the study it was found that the prevailing view was that severely malnourished children just needed feeding. The testimony that antibiotics were never given, even if prescribed, because, we thought that these children only needed to be fed, illustrates the gravity of this erroneous view. The consequence is that children are dying unnecessarily, and in large numbers.

The study revealed negative attitudes among many nurses towards malnourished children and their mothers, which in turn adversely affected the quality of care.

There was also lack of awareness of the profound physiological changes that take place in severe malnutrition and the need to consider these when providing treatment. Poor appetite, which is so common in malnutrition, was perceived as an idiosyncratic trait rather than a feature of infection. Consequently, little effort was made to overcome anorexia, apart from giving IV fluid and thus risking heart failure and death.

Training, on the other hand, altered these perceptions and helped nurses to have a better understanding of the causes of the presenting clinical signs, the importance of coaxing children to eat, feeding by naso-gastric tube, and correcting electrolyte imbalances and micronutrient deficiencies. This also provided a better insight into the need for antibiotics, the dangers of fluid overload and the importance of keeping children warm.

As far as the quality of care is concerned, the study revealed negative attitudes towards malnourished children and their mothers, with adverse effects. Lack of proper maternal care was seen as a major causal factor in the development of malnutrition, and this engendered reproachful attitudes to caregivers and resentment that was not seen with other illnesses. Malnourished children were seen as a burden that could have been avoided with proper care at home. Given this attitude, and considering the problem of understaffing, it is understandable why nurses may have felt demotivated and lowered their own standards of care as the following testimony indicates: We sometimes recorded the feeds without giving them to the child. Negativity was often strong, as exemplified by statements about the inevitability of death in malnourished children and the need to die.

In contrast, after training and seeing a reduction in mortality that is associated with implementing the WHO guidelines, motivation and quality of care improved. The nurses were also more likely to express sympathy rather than blaming caregivers.

How has this situation of poor attitudes and practices arisen? A major reason could lie within the nursing curriculum, which hardly features the treatment of severe malnutrition to any extent. Nurses 
are thus not adequately equipped to manage such children, a situation that needs to be rectified. Management of this condition is also not adequately dealt with in the curriculum for paediatric nursing.

Updating and upgrading the basic nursing curriculum should be a priority. This should include the physiological changes that occur in severe malnutrition along with the WHO treatment guidelines. In-service training is also needed. Materials already exist, such as the trainers' guide (Ashworth, et al., 2003:1-206) which includes overheads, role-plays etc. that can be utilised for training nurses, as well as the book that has been specially written with nurses in mind (Ashworth \& Burgess 2003:1-79). All the information needed to manage severely malnourished children is provided, and both the guide and book are available on CD ROM.

Case studies to practise different aspects of care are available from the first author (TP). Experience in the Eastern Cape, as illustrated in this article, has shown that in-service training changes both attitudes to malnutrition and treatment practices, as well as saving lives. Building on this experience, the Eastern Cape Department of Health has formed a cadre of volunteer nurse-trainers who can be called upon to support training in the province. Similar work has commenced in the provinces of Limpopo, Kwa-Zulu Natal, and North West where comparable situations have been found to exist.

\section{References}

ASHWORTH, A \& BURGESS, A 2003:

Caring for severely malnourished children. London: Macmillan. Also, Teaching-aids At Low Cost (TALC) [On Line]. Available: http://www.talcuk.org [2005, October 31].

ASHWORTH, A; CHOPRA, M; MCCOY, D; SANDERS, D; JACKSON, D; KARAOLIS, N; SOGAULA, N \& SCHOFIELD, C 2004: WHO guidelines for management of severe malnutrition in rural South African hospitals: effect on case fatality and the influences of operational factors. Lancet. 363: $1110-$ 1115.

ASHWORTH, A; PUOANE, T; SANDERS, D \& SCHOFIELD, C 2003: Improving the management of severe malnutrition. A guide for trainers.
Teaching-aids At Low Cost (TALC) [On Line]. Available: http://www.talcuk.org [2005, October 31].

PUOANE, T; SANDERS, D; CHOPRA, M; ASHWORTH, A; STRASSER, S; MCCOY,D; ZULU, B; MATINISE, N \& MDINGAZWE N 2001: Evaluating the clinical management of severely malnourished children - a study of two rural district hospitals. South African Medical Joumal. 91: 137-41.

PUOANE, T; SANDERS, D; ASHWORTH, A; CHOPRA, M; STRASSER, S \& MCCOY, D 2004: Improving the hospital management of malnourished children by participatory research. International Joumal for Quality in Health Care. 16: 31 - 40.

SCHOFIELD, C \& ASHWORTH, A 1996: Why have mortality rates for severe malnutrition remained so high? Bulletin of the World Health Organization. 74: 223-229.

\section{WORLD HEALTH ORGANIZATION}

2000: Management of the child with a serious infection or severe malnutrition: Guidelines for care at the first-referral level in developing countries. World Health Organization: Geneva. Also, [On Line]. Available:

http://www.who.int/child-adolescenthealth/ publications/referral_care/ homepage.html [2005, July 14]. 